\title{
The characteristics and roles of antimicrobial peptides as potential treatment for antibiotic-resistant pathogens: A review
}

\author{
Nurul Hana Zainal Baharin ${ }^{1,2}$, Nur Fadhilah Khairil Mokhtar ${ }^{2}$, Mohd Nasir Mohd Desa ${ }^{\text {Corresp., } 1,2}$, Banulata \\ Gopalsamy ${ }^{1}$, Nor Nadiha Mohd Zaki ${ }^{2}$, Mohd Hafis Yuswan ${ }^{2}$, AbdulRahman Muthanna ${ }^{1}$, Nurul Diana Dzaraly ${ }^{1}$, \\ Sahar Abbasiliasi ${ }^{2}$, Amalia Mohd Hashim ${ }^{2,3}$, Muhamad Shirwan Abdullah Sani ${ }^{4}$, Shuhaimi Mustafa ${ }^{3}$ \\ 1 Biomedical Science, Universiti Putra Malaysia, Serdang, Selangor, Malaysia \\ 2 Laboratory of Halal Science Research, Halal Products Research Institute, Universiti Putra Malaysia, Serdang, Selangor, Malaysia \\ 3 Department of Microbiology, Faculty of Biotechnology and Biomolecular Science, Universiti Putra Malaysia, Serdang, Selangor, Malaysia \\ 4 International Institute for Halal Research and Training (INHART), International Islamic University, Gombak, Selangor, Malaysia \\ Corresponding Author: Mohd Nasir Mohd Desa \\ Email address: mnasir@upm.edu.my
}

The emergence of antibiotic resistant bacteria has become a significant and everincreasing threat to global public health, increasing both morbidity and mortality rates, and the financial burden on health services. Infection by drug-resistant bacteria is anticipated to contribute to the demise of almost 10 million people by the year 2050 unless a competent and effective response is devised to engage with this issue. The emergence and spread of resistance is commonly caused by the excessive or inappropriate use of antibiotics and substandard pharmaceuticals. It arises when pathogens adapt to different conditions and develop self-defence mechanisms. Currently, novel antimicrobial peptides (AMPs) have been reported to be the sole cure for some clinical cases of infectious diseases such as sepsis and skin infections, although these agents may, on occasion, require administration together with an adjunctive low-dose antibiotic. Although AMPs are a promising alternative form of anti-microbial therapy and easily applied in the medical sector, they still have limitations that should not be taken lightly. Hence, this review explores the characteristics, advantages and disadvantages of AMPs for their potential in treating antibiotic-resistant pathogens. 
1 The characteristics and roles of antimicrobial peptides

2 as potential treatment for antibiotic-resistant

3 pathogens: A review

4 Nurul Hana Zainal Baharin ${ }^{1,2}$, Nur Fadhilah Khairil Mokhtar', Mohd Nasir Mohd Desa ${ }^{1,2 *}$,

5 Banulata Gopalsamy ${ }^{2}$, Nor Nadiha Mohd Zaki ${ }^{1}$, Mohd Hafis Yuswan ${ }^{1}$, AbdulRahman

6 Muthanna $^{2}$, Nurul Diana Dzaraly ${ }^{2}$, Sahar Abbasiliasi ${ }^{1}$, Amalia Mohd Hashim ${ }^{1,3}$, Muhamad

7 Shirwan Abdullah Sani ${ }^{4}$, Shuhaimi Mustafa ${ }^{1,3}$

$8{ }^{1}$ Laboratory of Halal Science Research, Halal Products Research Institute, Universiti Putra

9 Malaysia, 43400 UPM Serdang, Selangor.

$10{ }^{2}$ Department of Biomedical Sciences, Faculty of Medicine and Health Sciences, Universiti Putra 11 Malaysia, 43400 UPM Serdang, Selangor.

$12{ }^{3}$ Department of Microbiology, Faculty of Biotechnology and Biomolecular Science, Universiti 13 Putra Malaysia, 43400 UPM Serdang, Selangor.

14 International Institute for Halal Research and Training (INHART), International Islamic 15 University Malaysia, Gombak Selangor.

16 Corresponding Author:

17 Mohd Nasir Mohd Desa ${ }^{1,2 *}$,

18 Laboratory of Halal Science Research, Halal Products Research Institute, Universiti Putra

19 Malaysia.

20 Department of Biomedical Sciences, Faculty of Medicine and Health Sciences, Universiti Putra

21 Malaysia.

22 Email address: mnasir@upm.edu.my 


\section{Abstract}

24 The emergence of antibiotic resistant bacteria has become a significant and ever-increasing threat

25 to global public health, increasing both morbidity and mortality rates, and the financial burden on

26 health services. Infection by drug-resistant bacteria is anticipated to contribute to the demise of

27 millions of people in the future unless a competent and effective response is devised to engage

28 with this issue. The emergence and spread of resistance is commonly caused by the excessive or

29 inappropriate use of antibiotics and substandard pharmaceuticals. It arises when pathogens adapt

30 to different conditions and develop self-defence mechanisms. Currently, novel antimicrobial

31 peptides (AMPs) have been reported to be the sole cure for some clinical cases of infectious

32 diseases such as sepsis and skin infections, although these agents may, on occasion, require

33 administration together with an adjunctive low-dose antibiotic. Although AMPs are a promising

34 alternative form of anti-microbial therapy and easily applied in the medical sector, they still have

35 limitations that should not be taken lightly. Hence, this review explores the characteristics,

36 advantages and disadvantages of AMPs for their potential in treating antibiotic-resistant

37 pathogens. 
38

Antibiotics are anti-bacterial medications that inhibit or kill the growth of bacteria. It is usually competent in the treatment of pathogenic bacteria. However, antibiotics constantly lose their antibacterial strength as drug-resistant bacteria emerge with the misuse of the antibiotics (Gould \& Bal, 2013; Sengupta, Chattopadhyay \& Grossart, 2013; Wright, 2014). The antibiotic resistant bacteria are evolving worldwide, threatening the effectiveness of antibiotics, which have previously recovered millions of lives from infectious diseases (Golkar, Bagasra \& Pace, 2014; Gould \& Bal, 2013; Sengupta, Chattopadhyay \& Grossart, 2013; Wright, 2014). This scenario is becoming an important public health problem as it will lead to a prolonged hospital stay, increasing the cost of health care and risk of deaths (Golkar, Bagasra \& Pace, 2014; Ventola, 2015).

The finding for alternative antimicrobial agents with new mechanisms of action is of urgent need. Although some antibiotics are still effective in killing bacteria, long-term concerns about the good and bad effects of their usage remain to be taken seriously. Worryingly, the number of deaths caused by bacterial infections has risen dramatically, making it one of the leading factors of lifethreatening diseases (Morehead \& Scarbrough, 2018; World Health Organization, 2020).This problem arises due to the emergence of resistant infectious agents which is a major problem in the treatment of microbial infections (Ventola 2015). The attempts to discover other substances to replace the function of available antibiotics are still on going and being explored up to this day.

Antimicrobial peptides (AMPs) are one of the alternative components that may inhibit bacterial growth, possibly replacing the function of antibiotics in the future (Pfalzgraff, Brandenburg \& Weindl, 2018). These peptides can bind and interact with the negatively charged bacterial cell 
59

60

61

62

63

64

65

66

67

68

69

70

71

\section{Survey methodology} studies.

membranes, resulting in the disruption of the bacterial cell membrane. They cause damage to the cellular membrane, affecting the transportation of the large molecules such as proteins and ruining the morphology of the cells leading to cell death (Lei et al., 2019). Besides, some AMPs such as non-lytic AMPs including buforin II, indolicin and drosocin can also translocate across bacterial membrane to act on intracellular targets, including ribosomes (Cardoso et al., 2019; Le, Fang \& Sekaran 2017). These provide a good rationale for AMPs as a potential alternative for treatment of antibiotic-resistant pathogens. This paper provides an overview on the dilemma and impact of antibiotic resistance, followed by naturally occurring AMPs and synthetic AMPs analogues as a potent antimicrobial agent, in view of finding solutions and improving the quality of health worldwide. The advantages and disadvantages of AMPs are also discussed in relation to those of antibiotics. This paper is intended for all scientists and academicians in related fields to recognize the potential use of AMPs as a therapeutic agent and to serve as a reference for future related

We conducted a literature search covering publications in 2011 till 2021 in relevant topics. The keywords used in the search included "antimicrobial peptides", "antibiotic-resistance", "mechanisms of action", “AMPs", "bacteriocins", "bacterial resistance”, "mode of action”, "multidrug resistance", "naturally occurring AMPs" and "synthetic AMPs" through Google Scholar, Web of Science and PubMed Central platform. To ensure a comprehensive and unbiased coverage of the literature, all papers were assessed for information related to the crisis of antibiotic resistance; the history, sources and structure of AMPs; the bacterial resistance mechanisms and mechanisms of action of AMPs; and the benefits or limitations from the use of antibiotics and 
81 AMPs. The assessment of the data was performed by multiple individuals for articles in the different sections, followed by compilation and revision by first and corresponding authors.

\section{The Dilemma and Impact of Antibiotic Resistance}

Although the world is rapidly moving towards an era of globalization, especially in the field of medical technology, the problem of antibiotic resistance is something that cannot be denied when the number of deaths caused by bacterial infections has risen dramatically, making it as one of the leading factors of life-threatening diseases (Morehead \& Scarbrough, 2018). In early 1945, during the era of the discovery of penicillin, Sir Alexander Fleming had proclaimed and warned that antibiotics would one day be a highly demanded drugs and an era of abuse would emerge in the future (Spellberg \& Gilbert, 2014). Now, many cases of the microbial resistance against antibiotics are being reported year by year. For example, Gentamicin-Resistance Enterecoccus (GRE) was first reported to be resistant to vancomycin, the drug that is in use to treat Methicillin-Resistant Staphylococcus Aureus (MRSA) and Methicillin resistant coagulase-negative Staphylococci (MRCoNS) (Sengupta, Chattopadhyay \& Grossart, 2013).

The pharmaceutical industries have introduced many new antibiotics in the late 1960s to 2000s which include imipenem, ceftazidime, levofloxacin, linezolid, daptomycin and ceftaroline. However, over time, more and more bacterial resistance appears, and the number of new drug discovery steeply decreases. As a result, bacterial infection becomes a great threat to human health (Ventola, 2015). Worryingly, the genetic traits for antibiotic resistance can be transferred to other bacteria through horizontal gene transfer (HGT). Some resistance can also be caused by mutations at the genetic level of a bacterial cell leading to expression of altered target sites which is no longer 
102 recognized by the antibiotics. This has led to the difficulties in controlling bacterial infections, as

103 many antibiotics will not be able to exhibit similar effect over time and in different individuals

104 (Read \& Woods, 2014).

105 To avoid the adverse effects, the use of antibiotics should follow the guidelines in managing 106 infections. Excessive use of antibiotics and misuse can lead to many complications such as 107 diarrhea, indigestion, nausea, yeast infections or digestive problems. Incomplete use of antibiotics 108 will not help killing the germs effectively but will increase the selection of resistance to strive and 109 occupy the niche left by the susceptible strains. Antibiotics can also be toxic if not taken correctly 110 and could turn out to be hazardous if taken more than the recommended doses (Ventola, 2015).

111 Previously, a high percentage of antibiotic resistance was found in farm animals and reached 112 consumers through meat products (Bartlett, Gilbert \& Spellberg, 2013), resulting in the spreading 113 of bacterial resistance to human and adversely affecting human health (Centers for Disease Control 114 and Prevention, 2013). The use of antibiotics in agriculture also affects the microbial balance of 115 the environment (Bartlett, Gilbert \& Spellberg, 2013). Certain amount of antibiotics ingested by 116 livestock are excreted in their stools or urine. This causes widespread dissemination to the 117 environment when their stools are used as fertilizers, which can be absorbed into groundwater and 118 even soil (Bartlett, Gilbert \& Spellberg, 2013). Moreover, antibiotics namely tetracycline is used 119 as pesticides on plants. This practice causes long term adverse ecological consequences due to the 120 increase of resistant bacteria contaminating the environment (Golkar, Bagasra \& Pace, 2014).

121 The crisis of antibiotic resistance which is becoming increasingly pervasive today is having a 122 deleterious effect on the disease management. In general, infections caused by resistant bacterial 
123 strains are more severe than those by susceptible strains (Cosgrove \& Carmeli, 2003). For instance,

124 a significantly higher fatality rate has been reported for MRSA in comparison with that for

125 methicillin-susceptible S. aureus infection (Cosgrove \& Carmeli, 2003; Engemann et al., 2003).

126 The adverse effects of antibiotic resistance can be evaluated in accordance with several factors,

127 including an increase in patient mortality, greater resource utilisation, an escalation in the cost of

128 care and reduction in hospital activity (Friedman, Temkin \& Carmeli, 2016).

129 Mortality is the most severe consequence of antibiotic resistance. A report by Centers for Disease

130 Control and Prevention (CDC) in 2019, suggest that more than 2.8 million antibiotic resistance

131 associated infections occur in the United States every year, with over 35000 fatalities. The annual

132 increase in the number of cases has rendered the use of additional isolation rooms and consumable

133 items necessary, with comparable increases being required in nursing care, support services and

134 associated medical tests (diagnostic test and imaging), and these have placed a greater resource

135 utilisation and the overall cost of care (Friedman, Temkin \& Carmeli, 2016). In the wake of this,

136 a relatively substantial amount of hospital spending, in excess of $\$ 4.6$ billion annual basis, was

137 reported for the treatment of patients infected by antibiotic resistant bacteria (Centers for Disease

138 Control and Prevention, 2019). In addition, this crisis has been observed to rein in everyday

139 hospital activities, with elective operations being cancelled against a background of outbreaks of 140 antibacterial-resistant illnesses (Macraea et al., 2001).

\section{The Archival and the Diversity of AMPs}

142 AMPs have been in the focus as the alternative in addressing the problem of antibiotic resistance.

143 AMPs have been available naturally and synthetically; the history of naturally occurring AMPs 
144 and the evolution of synthetics AMPs are discussed in this topic and the analogies between these 145 two forms of AMPs are compiled in Table 1.

\section{1.The History of Naturally Occurring AMPs}

147 Naturally occurring AMPs that act as host defences are found in nearly all forms of life, and most 148 of them have been reported to be isolated from eukaryotes, such as animals, plants and fungi 149 (Kumar, Kizhakkedathu \& Straus, 2018). AMPs were also found in prokaryotic cells when 150 antimicrobial substances known as gramicidins were isolated from Bacillus brevis (Nakatsuji \& 151 Gallo, 2012). Historically, bacteria have been among the earliest sources of AMPs, and the 152 percentage of AMPs isolated from bacteria have the potential to increase in the future (Figure 1). 153 In 1939, Dubos extracted AMPs from Bacillus strain in soil to protect mice from pneumococcal 154 infections (Dubos, 1939). In a previous study, gramicidin showed antibacterial activity against 155 various Gram-positive bacteria (Dubos \& Hotchkiss, 1941). Gramicidin is effective in the 156 treatment of infected wounds on guinea pig skin and in the treatment of topical wounds and ulcers

157 (Van Epps, 2006; Gause. \& Brazhnikova, 1944), thus demonstrating their potential as the first 158 commercially used AMPs in the health industry. After that, in 1941, other AMPs isolated from bacteria, called tyrocidines, were found to be effective against Gram-negative and Gram-positive 160 bacteria (Dubos \& Hotchkiss, 1941).

161 In bacteria, AMPs help particular organisms by killing other bacterial species that compete for the 162 same nutrients and ecological niche. Known as bacteriocins, bacterial AMPs can be classified into 163 two classes: lantibiotics and non-lantibiotics. Lantibiotics are AMPs comprising the non-natural 164 amino acid lanthionine. In 1947, a type of lantibiotic AMPs isolated from Lactococcus lactis, 
165 known as nisin, was found to be active against a number of Gram-positive bacteria and historically

166 used as a preservative for many years without any noticeable growth of resistance (Mattick \&

167 Hirsch, 1947). Meanwhile, non-lantibiotics are AMPs composed of thermostable peptides which

168 do not contain lanthionine and do not undergo post-translational modifications (Heng \& Tagg,

169 2006). Garvicin Q (GarQ) is a type of non-lantibiotics AMPs with a relatively broad antimicrobial

170 spectrum towards Listeria and Lactococcus spp (Tymoszewska et al., 2017).

171 In plants, AMPs play an important role in their protection against the infection of bacteria or fungi.

172 In 1942, another AMPs, called purothionin, isolated from Triticum aestivum plants (Balls, 1942),

173 was detected to be effective against other bacteria (Ohtani et al., 1977). The thionin family is

174 among the best-studied groups of AMPs isolated from plants, apart from plant defensins and 175 cyclotides.

176 The highest diversity of AMPs was found in animals. For example, in 1956, AMPs named 177 defensins were discovered from rabbit leukocyte isolation (Hirsch, 1956). Later, in 1960, an AMP 178 called lactoferrin was successfully isolated from cow's milk (Groves, 1960), followed by the 179 synthesis of the AMPs known as bominins from epithelial cells in 1962 (Kiss \& Michl, 1962).

180 Several discoveries of AMPs from leukocytes have also been documented around 1970s and 181 1980s. Among these are rabbit-human $\alpha$-defensins and purothionin (Selsted, Szklarek \& Lehrer 182 1984; Selsted et al., 1993). In 1980, Hultmark et al. (1980) used silk butterflies as a model system 183 to successfully demonstrate that P9A and P9B could be induced in the hemolymph by co184 vaccination with Enterobacter cloacae. Shortly thereafter, these peptides were renamed as 185 cecropin until they became known as the major $\alpha$-helical AMPs (Hultmark et al., 1980). In 1987, 
186 Zasloff et al. (1987) isolated and characterized cationic AMPs from the African toad frog, Xenopus

187 laevis, and named them magainin peptides (Zasloff, 1987). A few years later, $\beta$-defensin and $\theta$ -

188 defensin were characterized after isolation from bovine granulocytes and from leukocytes of the

189 rhesus monkey, respectively (Diamond et al., 1991; Tran et al., 2002).

190 In the early 1990s, there were several views that lysozyme was one of the first AMPs to exhibit

191 antimicrobial activity involving non-enzymatic mechanisms. Based on these views, AMPs are seen

192 to have a role in the immunity of human that lacks an adaptive immune system (Diamond et al.,

193 2009). In the mid-1990s, several other peptides were also discovered, such as the first anionic

194 AMPs found in X. laevis, while other peptides in the rumen of sheep and cattle were characterized

195 (Brogden, Ackermann \& Huttner, 1997). In addition, AMPs have also been found in fruit flies,

196 called Drosophila melanogaster; by losing the genes encoding for AMPs in fruit flies will make

197 them susceptible to fungal infections. This shows the importance of AMPs in protecting flies from

198 microbial invasion (Lemaitre et al., 1996).

199 There are a lot of studies on AMPs that had been conducted to determine their ability to kill bacteria

200 and fight infections. AMPs exist in almost all multicellular organisms and play roles in the 201 mammalian immune system (Lemaitre et al., 1996). They have been widely identified in many 202 areas of the human body that are usually exposed to germ-like infections. AMPs are important in 203 innate modulation, as they can be produced naturally by various types of blood cells, including 204 neutrophils, eosinophils and platelets, in the event of inflammation or injury, supporting that AMPs 205 are among the agents responsible for fighting infections caused by germs (Diamond et al., 2009). 
207 In general, living organisms produce gene-encoded AMPs that provide an immediate defence

208 mechanism upon invasion by pathogens (Giannamaria \& Gabriele, 2020). However, the 209 application of AMPs in the clinical setting has been retsricted due to pharmaceutical limitations

210 such as poor bioavailability, susceptibility to enzymatic degradation and toxicity (Deslouches et

211 al., 2020; Costa et al., 2019). For this reason, synthetic AMPs that can maintain therapeutic

212 effectiveness with higher biological stability and a greater safety profile continue to be developed.

213 Most synthetic AMPs are designed to recapture the amphiphilic properties of natural AMPs which

214 are believed to be the primary determinants of their antibacterial activity. In other words, the 215 natural peptides will be modified to produce de novo scaffolds that resemble the parent peptides 216 (Azmi, Skwarczynski \& Toth, 2016).

217 Historically, various methods were used to optimize AMPs from natural occurring sources, 218 thus generating synthetic variants. In 1881, the azide-coupling method was used by treating the 219 silver salt of glycine with benzoylchloride to create the first N-protected dipeptide, 220 benzoylglycylglycine. Nevertheless, in 1901, Emil Fischer reported the first synthetic dipeptides 221 by hydrolysis of the glycine diketopiperazine, known as glycylglycine (Lichtenthaler, 2002). The 222 development of temporary amino-protecting groups was required to overcome synthetic 223 challenges. In 1931, the carbobenzoxy (Cbz) group was introduced, followed by the the ert224 butyloxycarbonyl (Boc) group in 1957 (Anderson \& McGregor, 1957; Grapsas, Cho \& 225 Mobashery, 1994). The discovery of solid phase peptide synthesis (SPSS) was achieved in 1963, 226 when peptide sequences were synthesized on solid support (Merrifield, 1963). However, the major 227 limitations of SPSS included insufficient coupling and degradation reactions, as well as a build-up 228 of by-products (Pedersen et al., 2012; Schnölzer et al., 2009; King et al., 2009). For that reason, 229 several new techniques of protein synthesis have been developed to overcome the limitations of 
230 SPPS. For example, chemical ligation and coupling two peptide fragments together were

231 introduced (Kemp et al, 1981). Other ligation methods such as native chemical ligation (NCL),

232 expressed protein ligation (EPL), and Staudinger ligation were also introduced to overcome the

233 constraint (Dawson et al., 1994).

To date, methods for producing synthetic AMPs are constantly being improved. For example, using cationic peptides based on natural templates is becoming one of the most exciting new strategies for synthesizing AMPs today. These AMPs have complex mechanisms of action and do not readily lead to resistance. With their anti-inflammatory properties, as well as antimicrobial synergy, they hold promises as adjunctive strategies to supplement and enhance current therapies (Fjell et al., 2012). Several computational tools have also evolved in the development of more economical and powerful synthetics AMPs (Cardoso et al., 2019). For instances, the empirical methods, machine learning and de novo computational methods are being used in the optimization of peptides through random processes (Porto et al., 2012). Genetic algorithms also offer an alternative in the development of synthetic AMPs by identifying antibacterial activity-conferring determinants through successive generations of mutations and deletions in the target sequence (Kliger, 2010; Fjell et al., 2011). These candidates are refined over time as lower fitness values are removed from the candidate sequences (Fjell et al., 2011). (Wimley, 2019). Previoulsy, naturally occuring AMPs are used as templates to optimize their activity and stability by mutating one or more amino acid residues; this was followed by the de novo design of a variety of synthetic peptides, peptoids, peptidomimetics, oligomers and polymers

251 (Jiang et al., 2021). An example is iseganan, where protegerin is used as the template and one or more amino acid residues has been mutated to other proteinogenic L-amino acids to achieve 
253 antimicrobial activity against gram-negative and gram-positive bacteria (Trotti et al., 2004). There

254 are several other examples of synthetic AMPs that are produced using this approach, such as

255 omiganan, which is developed using indolicin; and pexiganan,which in turn, is developed by

256 magainin 2 (Ge et al., 1999; Gottler \& Ramamoorthy, 2009; Sader et al., 2004).

257 Another way of producing synthetic AMPs is utilization of $\beta$-amino acids as the building blocks

258 or using non-natural N-substituted amino acids (Jiang et al., 2021). For example, synthesized

259 helical $\beta$-peptide that was developed from $\beta$-amino acid; and synthesized oligo-N-substituted-

260 glycine-based helical peptoid that was developed by magainin 2 amide. Both of these synthetic

261 AMPs show greater and more stable antibacterial activity compared to naturally occuring AMPs

262 (Chongsiriwatana et al., 2008; James \& Annelise, 2003; Richard \& Samuel 2001). Generally,

263 synthetic AMPs are more stable and possess better activity and selectivity compared to naturally

264 occuring AMPs. However, the limitations of producing synthetic AMPs include the extended time

265 required to do so and the high cost (Jiang et al. 2021).

\section{The Structures of AMPs}

267 To clearly identify the potential of AMPs, the structure of AMPs needs to be well elucidated.

268 AMPs are relatively short molecules, containing 12-100 amino acids with an amphipathic

269 structure (Hodges et al., 2011). Several databases exist that manage information and conduct

270 peptide analysis, due to the high numbers of natural, semi-synthetic and synthetic AMPs

271 (Mahlapuu et al., 2016). AMPs can be classified based on their structure, amino acid composition

272 and size. The structural features of AMPs can be divided into four main groups, (1) peptides with 
273 amphipathic $\alpha$-helices (2) $\beta$ sheets, (3) combined $\alpha$-helices and $\beta$ sheet structures ( $\alpha \beta)$ known as a

274 mixed structure and (4) non- $\alpha \beta$ structure known as extended structure (Figure 2).

$275 \alpha$-helical peptides are the most widely studied types of AMPs to date. The $\alpha$-helical peptide has

276 two amino acids adjacent to each other with a distance of $0.15 \mathrm{~nm}$ between them; the centre is

277 about 100 degrees from the top view. Among the well-known peptides studied in this group are

278 LL-37 and human lactoferricin (Epand and Vogel 1999; Hunter et al. 2005; Legrand et al. 2005;

279 Pasupuleti 2011). In addition, among the other widely studied AMPs are colistin, melittin, nisin,

280 and Cecropin A-Magainin 2 (CAMA) (Bechinger \& Lohner, 2006; Kumar, Kizhakkedathu \&

281 Straus, 2018).

$282 \beta$-sheet peptides are composed of at least two $\beta$ strands with disulfide bonds between these sheets.

283 Interestingly, almost all $\beta$-sheet AMPs contain preserved cysteine residues and form disulphide

284 bonds such as gomesin, polyphemusin, protegerin and tachyplesin (Kumar, Kizhakkedathu \&

285 Straus, 2018). However, some studies have reported short $\beta$-sheet forming AMPs that do not have

286 disulfide bonds (Cândido et al., 2019; Ong et al., 2014; Ong, Gao \& Yang, 2013). For example,

287 the synthetic $\beta$-sheet AMP known as IK8-all D (irikirik- $\mathrm{NH}_{2}$ ) which is derived from $\beta$-sheet

288 forming peptides (IRIK) $)_{2}-\mathrm{NH}_{2}(\mathrm{IK} 8$-all L) has shown no formation of disulfide bonds in its design

289 (Ong et al., 2014).

290 Besides $\alpha$-helical peptides and $\beta$-sheet peptides, there is a kind of AMP structure that had been

291 found with the formation of $\alpha$-helices and $\beta$-sheets $(\alpha \beta)$ (mixed structure). In this class of AMPs,

292 the two monomers are packed against each other with the $\beta$-sheet of one monomer facing the $\alpha$ -

293 helix of another monomer (Kovaleva et al., 2020). Human $\beta$-defensin-2 and pine defensin 1 
294 (PsDef1) are among the peptides studied in this group (Jenssen, Hamill \& Hancock, 2006;

295 Kovaleva et al., 2020).

296 Extended/random coil AMPs display another unique structure that has been frequently discussed.

297 This structure consist of two or more proline residues, tryptophan, arginine and histidine which

298 have the capabilities to break the secondary structure elements (Bahar \& Ren, 2013). In addition,

299 many peptides such as indolicin and moricin, adopt their active structure only after they interact

300 with the target cell membrane. Indolicin is a hemolytic AMP isolated from bovine neutrophils. It

301 is effective as an antimicrobial agent because it has 13 tridecapeptide amides and an extremely

302 high tryptophan content (Cardoso et al., 2019). Indolicin changes its structural profile to a "boat-

303 like"and transmembrane orientation to translocate the bacterial membrane and act on DNA

304 (Cardoso et al., 2019). Moricin is a random coil AMP that was isolated from Manduca sexta. It

305 consists of one aspartic acid, two arginine and nine lysine residues and features $\alpha$-helical structures

306 to perform their membrane-associated or intracellular mechanisms of action (Dai et al., 2008)

307 Apart from those, there have been progressively increasing reports in newly discovered AMPs

308 with cyclic and disulfide-rich AMPs as well as AMPs with more complex topologies in the past

309 two decades. Some studies reported these as a fifth class of AMPs (Koehbach \& Craik, 2019).

310 These peptides have been identified based on the nature of the peptide's cyclic topology such as

311 "head to tail" or "head to side chain" as well as the nature of the crosslinks such as the presence

312 of disulfide or thioether bridges (Koehbach \& Craik, 2019). For example, microcin J25 (lasso

313 peptides) have been found with a head-to-side chain cycle (magenta) threaded by the C-terminal

314 tail and sterically locked in place by bulky residues (cyan) (Rosengren et al., 2003). 


\section{The Bacterial Resistance Mechanisms towards Antibiotics and the 316 Way AMPs can help}

317 Understanding on the mechanisms of antibiotic resistance will allow the relevance of AMPs to be

318 seen as a potential alternative for antibiotics. Antibiotic resistance mechanisms in bacteria and how

319 AMP mechanisms aid in killing bacteria are depicted in Figure 3. This figure displays four major

320 molecular mechanisms by which bacteria can withstand antibiotic effects. Among these are drug-

321 target modifications, antibiotic-degrading enzymes, antibiotic-altering enzymes and antibiotic

322 efflux pumps (Laws, Shaaban, \& Rahman, 2019). These resistance mechanisms can occur in one

323 bacterial cell simultaneously, resulting in high levels of resistance to various antibiotic compounds

324 (Peterson \& Kaur, 2018). In addition to these four major mechanisms, bacterial biofilm has also

325 attracted a great attention in resistance mechanisms towards antibiotics. Bacteria that attach to the

326 surface and grow as biofilm are protected from killing by antibiotics, thus makes the treatment

327 difficult (Dincer, 2020).

328

329

330

331

332

333

334

335

336

337
Meanwhile, most of the AMPs were found to kill bacterial cells by disrupting the bilayer membrane without the interference of all the available antibiotic resistance characters that might be present in a bacterial cell. However, there are studies indicating that bacteria can resist AMPs treatment at sub-lethal doses and expel them by efficient efflux pumps (Cardoso et al., 2017). Membrane interactions are important in the direct antimicrobial activity of AMPs (Hollmann et al., 2018; Lei, J. et al., 2019). Several models have been introduced to explain the mechanism of disrupting bilayer membranes by AMPs. These models are the barrel-stave model, the toroidalpore model, and the carpet model. In the barrel-stave model, recruitment of additional peptides placed perpendicularly into the bilayer will lead to the formation of a peptide-lined transmembrane pore. In this pore, the peptides align with the hydrophobic side facing the lipid core of the 
338 membrane, while the hydrophilic regions face the interior region of the pore. In the toroidal-pore

339 model, phospholipids bend continuously from one leaflet to another due to the interaction of

340 AMPs. This then results in a pore lined by both peptides and the head groups of phospholipids.

341 For the carpet model, the mechanism is explained by the formation of micelles due to membrane

342 disruptions by the tension in the bilayer as a result of peptide accumulation (Mahlapuu et al., 2016).

343 Intracellular targeting and inhibition of protein synthesis also act as targets by which some of the

344 AMPs may interfere and express their function and ability to disrupt the cell growth. To reach the

345 cytoplasmic membrane of Gram-negative bacteria, AMPs will translocate through the outer

346 membrane via a self-promoted uptake (Le, Fang \& Sekaran, 2017; Mahlapuu et al., 2016).

347 Moreover, activated AMPs cause damages to bacterial cells by attacking an internal target or

348 translocating across the membrane receptors, entering the bacterial cytoplasm and disrupting

349 intracellular targets (Jindal, Le \& Yusof, 2015; Malanovic \& Lohner, 2016). Bacterial destruction

350 also occurs by the interaction between the electrostatic forces of the positively charged amino

351 acids of the AMPs and the negatively charged cell surface. These create an ion-permeable channel

352 and increase membrane permeability to develop cleavages (Lin \& Weibel, 2016).

353 The translocation of AMPs will not only disrupt the cellular membrane but also target some

354 important processes, such as DNA transcription and replication, RNA synthesis and protein

355 synthesis, enzymatic activity, protein folding or cell wall synthesis (Le, Fang \& Sekaran, 2017).

356 For example, indolicin acts by targeting DNA and inhibiting the replication process, indirectly

357 killing the bacteria. Bacterial death caused by AMPs could be the result of multiple and

358 complementary actions. The mode of action of AMPs depends on several factors, including peptide 
359 concentrations, the targeted bacterial species, tissue localization and the bacterial growth phase

360 (Kumar, Kizhakkedathu \& Straus, 2018; Mahlapuu et al., 2016).

361 Bacterial cytoplasmic membranes are rich with negatively charged phospholipids, including

362 phosphatidylglycerol, cardiolipin and phosphatidylserine, all of which are highly attracted to the

363 positive charges of AMPs (Ebenhan et al., 2014). Gram-negative bacteria consist of an additional

364 lipopolysaccharide-rich outer membrane that acts as a barrier to the cytoplasmic membranes. The

365 presence of teichoic acids in the cell wall of Gram-positive bacteria also provide an additional

366 electronegative charge to the bacterial surface (Ebenhan et al., 2014). As opposed to bacteria,

367 human cells seem to be rich in neutrally charged phospholipids, such as phosphatidylethanolamine,

368 phosphatidylcholine and sphingomyelin. This fundamental difference between microbial and

369 mammalian membranes has made AMPs a highly selective agent against bacteria (Ebenhan et al.,

370 2014). The presence of cholesterol in humans affects the fluidity of the phospholipid in the

371 membranes via an increased stability of the bilayer, then, reduce the activity of AMPs via

372 stabilization of phospholipids bilayer (Subczynski et al., 2018).

\section{The Advantages and Disadvantages of AMPs}

374 In developing AMPs as the potential treatment for antibiotic-resistant pathogens, the advantages

375 as well as the limitations of AMPs should be considered and are discussed in this topic.

377 The long-term and overly frequent use of conventional antibiotics as antibacterial agents has the

378 potential to cause mutations in the bacterium, thereby increasing resistance to the antibiotics 
379 themselves (Bahar \& Ren, 2013). This issue has prompted researchers and the pharmaceutical

380 industry to focus on identifying drugs capable of replacing antibiotics. AMPs are a type of cationic

381 peptide, an agent thought to be able to fulfil the role of antibiotics. Unlike antibiotics, AMPs

382 interact with the cell membrane of bacteria by neutralizing the charge and, subsequently, causing

383 bacterial death by penetrating the membrane, thereby reducing the risk of bacterial resistance

384 (Mahlapuu et al., 2016). This ability on the part of AMPs indicates them to be more effective than 385 conventional antibiotics.

386

387

388

389

390

391

392

393

394

395

396

397

398

399

400

AMPs have demonstrated a wide range of capabilities in killing bacteria as well as fungi and viruses (Amso \& Hayouka, 2019; Mahlapuu et al., 2016). Interestingly, AMPs have less side effects on the hosts, as their uses cause a very minimal toxicity to the body based on previous studies (Zharkova et al., 2019; Lei, J. et al., 2019; Mahlapuu et al., 2016). For example, a peptide known as citrus-amp1, which is isolated from citrus, exhibited low toxicity effects when tested on Galleria mellonella, a cell line derived from the larval-fat body tissues of the wax moth, and on U87 MG, a human glioblastoma cell line commonly used as a model for cytotoxicity (Kishi et al., 2018). A peptide known as Nisin A also presented low toxicity effects when tested on HT29 and Caco-2 cells by using MTT assay (Maher \& McClean, 2006).

AMPs with a simple structure-activity relationship are widely used in the development of medicines. They are particularly useful in this regard because they are associated with excellent water stability and solubility (Dehsorkhi, Castelletto \& Hamley, 2014). For example, daptomycin, another type of AMPs, has been used as an anionic antibacterial peptide to treat skin infections stemming from Gram-positive bacteria, thereby showing inhibitory effects on $S$. aureus and typhoid bacillus Salmonella typhi (Lei, J. et al., 2019). 
401 Additionally, AMPs have also demonstrated a good inhibition of cancer cells (Mahlapuu et al.,

402 2016). In fact, cancer cells are more sensitive to AMPs than normal cells. This is because the

403 cytoskeletons of cancer cells do not grow well when compared with those of normal cells, which

404 allows AMPs to easily enter the lipid membrane and form ion channels or pores. This process

405 eventually destroys the cancer cells by causing the leakage of the cell content (Jäkel et al., 2012;

406 Mahlapuu et al., 2016). More specifically, the content of those cationic AMPs associated with the

407 high acid phospholipids that occupy the outer surface of cancerous cell causes changes in the 408 membrane, extracellular matrix and cytoskeleton (Mahlapuu et al., 2016). The loss of 409 phospholipids asymmetry in cancer cells provides them with more negatively charged residues in

410 their upper leaflet, thus favouring electrostatic attraction of AMPs (Martín \& Amelio, 2021). In

411 terms of acting as antimicrobial agents, AMPs have the potential to fight antibiotic-resistant

412 bacteria. The bactericidal effect of AMPs is generally due to the creation of pores in the bacterial

413 cytoplasmic membrane, which results in a loss of control over the flow of ions through the 414 membrane and, consequently, cell deaths. This renders the use of AMPs a promising strategy for 415 addressing the problem of antibiotic resistance through fulfilling the role of conventional 416 antibiotics (Lei, J. et al., 2019).

417 2. Disadvantages of AMPs

418 Despite the uniqueness and recognised advantages of AMPs, concerns have been raised about 419 certain disadvantages of their excessive use that may eventually lead to emergence of resistance 420 against AMPs as bacteria will always mutate for survival. Among other disadvantages include 421 several aspects such as toxicity, immunogenicity, haemolytic activity in certain type of human 422 cells, reduced activity based on salt sensitivity, and the high cost of production (Aoki \& Ueda, 
423 2013; Moravej et al., 2018). These characteristics render the use of AMPs in the field of medicine

424 more difficult.

425 There have been challenges in classifying the good AMPs and AMPs that can cause side effects.

426 In some cases, the use of AMPs is associated with a high risk of toxic effects in human cells. For

427 example, certain peptides such as arenicin, LTX-109 and LL-37 have been found to cause side

428 effects (itching, burning and pain) to mammalian cells in vitro and, further, to be toxic with the

429 formation of pore at the membrane, disruption of the membrane and cell lysis, when injected into

430 the bloodstream (Patrulea, Borchard \& Jordan, 2020). This problem urges research to look for

431 more new AMPs compounds with less toxicity effects. In addition, although AMPs have been

432 reported not to elicit an immunogenic response (no interference from the action of the host cell),

433 immunogenicity continues to be a concern and even a serious problem in the development of the

434 peptide drugs (Mahlapuu et al., 2016). Based on previous findings, structural properties such as

435 the changes in peptide sequences (modified amino acids), glycosylation changes, the presence of

436 aggregates and other possible factors have been identified as the factors that can lead to

437 immunogenicity of AMPs (da Cunha et al., 2017; Natalia, Brendan \& Sam., 2017). These factors

438 may cause the function of AMPs to be disrupted.

439 A certain number of AMPs have been reported to influence haemolytic activity. Indolicidin, for example, a 13-residue cationic peptide that is rich in tryptophan, has been found to exhibit a broad

441 spectrum of anti-bacterial activity, however it exhibits haemolytic activity that limits their clinical

442 applications (Mirski et al., 2018). Some types of AMPs can interact directly with the host cell and

443 dissolve it, although most AMPs bind to the bacterial opening through electrostatic interactions.

444 The amide peptides exhibit higher antimicrobial activity than natural AMPs, although they are 
445 more haemolytic. In addition, the functional analysis of AMPs has demonstrated how their high

446 amphiphilicity and high hydrophobicity contribute to their increased haemolytic capability (Aoki

447 \& Ueda, 2013; Bahar \& Ren, 2013). However, the haemolytic activity of several AMPs was

448 observed to be different in certain types of different species. For example, based on a previous

449 study, 24 AMPs were evaluated for their haemolytic activity in cells of four different species such

450 as human, dog, rat and bovine. Based on this study, some of the AMPs showed no or less

451 haemolytic activity towards each species, and vice versa (Greco et al., 2020). More thorough

452 studies need to be conducted to identify the most appropriate AMPs that do not cause harm to

453 human.

454 The fact that some AMPs require electrostatic interactions with microbial membranes to form a 455 skeletal structure has caused them to be more sensitive to salt, which often leads to problems with 456 clinical applications (Andersson, Hughes \& Kubicek, 2016; Hollman et al., 2018). Human body 457 fluids that have a high salt concentration disrupt the function of these AMPs and, therefore, 458 deactivate those (Bastos, Ferreira \& Vitorino, 2017). Thus, the identification of salt-resistant 459 AMPs is essential to improve the effectiveness of AMPs within the human body. AMPs are also 460 rapidly degraded in human body by proteases (Aoki \& Ueda, 2013). A feasible production method 461 is required to develop AMPs as drugs. Further studies need to be conducted in this regard, and 462 such efforts will require a lot of investments. For instance, the production of heterologous AMPs 463 within prokaryotic systems is considered to be extremely difficult, as AMPs are associated with 464 the poisoning risk in prokaryotic cells (Aoki \& Ueda, 2013). 


\section{Conclusion}

466 Physicians and scientists describe the antibiotic resistance crisis as increasingly threatening. This

467 problem may worsen unless the public takes precautionary measures. This issue has prompted

468 research to look for new antimicrobials, leading to ongoing research on the AMPs. However, the

469 development has been slow due to several challenges such as high cost of salvage, potential

470 toxicity and lack of solid guideline for rational design. In addition, it might be possible to modify

471 the characteristics of naturally occurring AMPs to produce synthetic AMPs through certain

472 available methods, but to predict the impact of these modifications in clinical usage is still

473 challenging. Thus, there is a need to observe the effects of structural modifications on their

474 function, activity, and target spectrum. On the other hand, the mechanisms of action of AMPs

475 targeting the cell membrane, make them as a good potential approach in controlling the antibiotic

476 resistant pathogen. A close collaboration between different disciplines and the development of

477 new tools that can decipher the structure-function relationship, as well as efficiently synthesize

478 and modify AMPs molecules will be the key to AMPs related research in the future.

\section{List of abbreviations}

480 AMPs (Antimicrobial peptides); GRE (Gentamicin-Resistance Enterecoccus); MRSA 481 (Methicillin-Resistant Staphylococcus Aureus); MR-CoNS (Methicillin resistant coagulase482 negative Staphylococci); HGT (horizontal gene transfer); CAMA (Cecropin A-Magainin 2); DNA 483 (Deoxyribonucleic acid); RNA (Ribonucleic acid); U87 MG (Uppsala 87 Malignant Glioma); LL48437 (form of LL-37); X. laevis (Xenopus laevis); solid phase peptide synthesis (SPSS); native 485 chemical ligation (NCL); expressed protein ligation (EPL). 


\section{Acknowledgements}

487 We would like to thank Laboratory of Halal Science Research (LAPSAH), Universiti Putra

488 Malaysia (UPM) for supporting this work. We would also like to acknowledge Ministry of Higher

489 Education, Malaysia under the Fundamental Research Grant Scheme (grant numbers; 5540047 and 490 5540412) for funding this study.

491

492

493

494

495

496

497

498

499

500

501

502

503

504

505

506

507

508

509

510

511

512

513

514

515

\section{References}

Amso Z, Hayouka Z. 2019. Antimicrobial random peptide cocktails: a new approach to fight pathogenic bacteria. Chemical Communication 55: 2007-2014 DOI:10.1039/C8CC09961H.7-14.

Anderson GW, McGregor AC. 1957. t-Butyloxycarbonylamino acids and their use in peptide synthesis. Journal of American Chemical Society 79: 6180-6183 DOI: $10.1021 / \mathrm{ja} 01580 \mathrm{a} 020$

Andersson DI, Hughes D, and Kubicek-Sutherland JZ. 2016. Mechanisms and consequences of bacterial resistance to antimicrobial peptides. Drug Resistance Updates 26: 43-57 DOI:10.1016/j.drup.2016.04.002.

Annunziato G, Costantino G. 2020. Antimicrobial peptides (AMPs): a or a patent review (20152020). Expert Opinion on Therapeutic Patents 30: 931-947 DOI: 10.1080/13543776.2020.1851679.

Aoki W, Ueda M. 2013. Characterization of antimicrobial peptides toward the development of novel antibiotics. Pharmaceuticals 6: 1055-1081 DOI: 10.3390/ph6081055.

Azmi F, Skwarczynski M, Toth I. 2016. Towards the development of synthetic antibiotics: designs inspired by natural antimicrobial peptides. Current Medicinal Chemistry 23: 4610-4624 DOI:10.2174/0929867323666160825162435.

Bahar AA, Ren D. 2013. Antimicrobial peptides. Pharmaceuticals 6: 1543-1575 DOI:10.3390/ph6121543.

Balls AK. 1942. A crystalline sulphur-protein from wheat. Journal of Washington Academy of Sciences 32: 132-137.

Bartlett JG, Gilbert DN, Spellberg B. 2013. Seven ways to preserve the miracle of antibiotics. Clinical Infectious Diseases 56: 1445-1450 DOI: 10.1093/cid/cit070

Bastos P, Trindade F, da Costa J, Ferreira R, Vitorino R. 2018. Human antimicrobial peptides 
516

in bodily fluids : current knowledge and therapeutic perspectives in the postantibiotic era. Medicinal Research Reviews 38: 101-146 DOI: 10.1002/med.21435.

Bechinger B, Lohner K. 2006. Detergent-like actions of linear amphipathic cationic antimicrobial peptides. Biochimica et Biophysica Acta - Biomembranes 1758: 15291539 DOI: 10.1016/j.bbamem.2006.07.001.

Brogden KA, Ackermann M, Huttner KM. 1997. Small, anionic, and charge-neutralizing propeptide fragments of zymogens are antimicrobial. Antimicrobial Agents and Chemotherapy 41: 1615 - 1617 DOI: 10.1128/AAC.41.7.1615

Cândido ES, Cardoso MH, Chan LY, Torres MDT, Oshiro KGN, Porto WF, Ribeiro SM, Haney EF, Hancock REW, Lu TK, de la Fuente-Nunez C, Craik DJ, Franco OL. 2019. Short cationic peptide derived from archaea with dual antibacterial properties and antiinfective potential. ACS Infectious Diseases 5: 1081-1086 DOI: 10.1021/acsinfecdis.9b00073.

Cardoso MH, de Almeida KC, Candido ES, Murad AM, Dias SC, Franco OL. 2017. Comparative nanoUPLC-MSE analysis between magainin I-susceptible and -resistant Escherichia coli strains. Scientific Reports 7: 4197 DOI: 10.1038/s41598-017-04181-y.

Cardoso MH, Meneguetti BT, Costa BO, Buccini DF, Oshiro KGN, Preza SLE,Carvalho CME, Migliolo L, Franco OL. 2019. Non-lytic antibacterial peptides that translocate through bacterial membranes to act on intracellular targets. International Journal of Molecular Sciences 20:4877 DOI: 10.3390/ijms20194877.

Centers for Disease Control and Prevention. 2013. Antibiotic resistance, food, and food animals. Availabel at https://www.cdc.gov/foodsafety/challenges/antibioticresistance.html (accessed January 28, 2015).

Cheng RP, Gellman SH, DeGrado WF. 2001. $\beta$-Peptides: from structure to function. Chemical Review. 101: 3219-3232 DOI: 10.1021cr000045i.

Chongsiriwatana NP, Patch JA, Czyzewski AM, Dohm MT, Ivankin A, Gidalevits D, Zuckermann RN, Barron AE .2008. Peptoids that mimic the structure, function, and mechanism of helical antimicrobial peptides. Proceedings of the National Academy of Sciences of the United States of America 105: 2794-2799 DOI: 10.1073 /pnas.0708254105.

Costa F, Teixeira C, Gomes P, Martins MCL. 2019. Clinical application of AMPs. Antimicrobial Peptides. Advances in Experimental Medicine and Biology 1117: 281298 DOI: 10.1007/978-981-13-3588-4_15.

Cosgrove SE, Yehuda C. 2003. The impact of antimicrobial resistance on health and economic outcomes. Clinical Infectious Diseases 36: 1433-1437 DOI: 10.1086/375081.

da Cunha NB, Cobacho NB, Viana JFC, Lima LA, Sampaio KBO, Dohms SSM, Ferreira ACR, de la Fuente-Núñez C, Costa FF, Franco OL, Dian SC. 2017. The next generation of 
antimicrobial peptides (AMPs) as molecular therapeutic tools for the treatment of diseases with social and economic impacts. Drug Discovery Today 22: 234-248 DOI: 10.1016/j.drudis.2016.10.017.

Dai H, Rayaprolu S, Gong Y, Huang R, Prakasha O, Jiang H. 2008. Solution structure, antibacterial activity, and expression profile of Manduca sexta moricin. Journal of Peptide Science. 14: 855-863 DOI: 10.1002/psc.1016.

Dawson PE, Muir TW, Clark-Lewis I, Kent SB. 1994. Synthesis of proteins by native chemical ligation. Science.4;266(5186): 776-9. DOI: 10.1126/science.7973629. PMID: 7973629.

Dincer S, Uslu FM, Delik A. 2020. Antibiotic resistance in biofilm IntechOpen. DOI: 10.5772/intechopen.92388.

Dehsorkhi A, Castelletto V, Hamley IW. 2014. Self-assembling amphiphilic peptides. Journal of Peptide Science 20:453-467 DOI: 10.1002/psc.2633.

Deslouches B, Ronald CM, Ken LU, Yuanpu PD. 2020. Engineered cationic antimicrobial peptides (ECAPs) to combat multidrug-resistant bacteria. Pharmaceutics 12: 501 DOI: 10.3390/pharmaceutics12060501.

Diamond G, Zasloff M, Eck H, Brasseur M, Maloy WL, Bevins CL. 1991. Tracheal antimicrobial peptide, a cysteine-rich peptide from mammalian tracheal mucosa: peptide isolation and cloning of a cDNA. Proceedings of the National Academy of Sciences of the United States of America 88: 3952-3956 DOI: 10.1073/pnas.88.9.3952.

Diamond G, Beckloff N, Weinberg A, Kisich KO. 2009. The roles of antimicrobial peptides in innate host defense. Current pharmaceutical Design 15: 2377-2392 DOI: $10.2147 / 138161209788682325$.

Dubos RJ. 1939. Studies on a bactericidal agent extracted from a soil Bacillus: I. Preparation of the agent. Its activity in vitro. Journal of Experimental Medicine 70: 1-10 DOI: 10.1084/jem.70.1.1.

Dubos RJ, Hotchkiss RD. 1941. The production of bactericidal substances by aerobic sporulating bacilli. Journal of Experiment Medicine 73:629-640 DOI: 10.1084/jem.73.5.629.

Ebenhan T, Gheysens O, Kruger HG, Zeevaart JR, Sathekge MM. 2014. Antimicrobial peptides: their role as infection-selective tracers for molecular imaging. BioMed Research International 2014:867381 DOI: 10.1155/2014/867381.

Engemann JJ, Carmeli Y, Cosgrove SE, Fowler VG, Bronstein MZ, Trivette SL, Briggs JP, Sexton DJ, Kaye KS . 2003. Adverse clinical and economic outcomes attributable to Methicillin resistance among patients with Staphylococcus aureus surgical site infection. Clinical Infectious Diseases 36: 592-598 DOI: 10.1086/367653.

Epand RM, Vogel HJ. 1999. Diversity of antimicrobial peptides and their mechanisms of 
589

590

591

592

593

594

595

596

597

598

599

600

601

602

603

604

605

606

607

608

609

610

611

612

613

614

615

616

617

618

619

620

621

622

623

624

action. Biochimica et Biophysica Acta - Biomembranes 1462: 11-28 DOI: 10.1016/S0005-2736(99)00198-4.

Fjell CD, Jenssen H, Cheung WA, Hancock RE, Cherkasov A. 2011. Optimization of antibacterial peptides by genetic algorithms and cheminformatics. Chemical Biology and Drug Design 77: 48-56 DOI: 10.1111/j.1747-0285.2010.01044.x

Fjell C, Hiss J, Hancock R. et al. 2012. Designing antimicrobial peptides: form follows function. Nature Reviews Drug Discovery 11: 37-51 DOI: 10.1038/nrd3591

Friedman ND, Temkin E, Carmeli Y. 2016. The negative impact of antibiotic resistance. Clinical Microbiology and Infection 22: 416-422 DOI: 10.1016/j.cmi.2015.12.002.

Gause GF, Brazhnikova MG. 1944. Gramicidin $S$ and its use in the treatment of infected wounds. Nature 154:703 DOI: 10.1038/154703A0.

Ge Y, MacDonald DL, Holdray KJ, Thornsberry C, Wexler H, Zasloff M. 1999. In vitro antibacterial properties of pexiganan, an analog of magainin. Antimicrobial Agents and Chemotherapy 43: 782-788 DOI: 10.1128/AAC.43.4.782.

Giuliani A, Pirri G, Nicoletto SF. 2007. Antimicrobial peptides : An overview of a promising class of therapeutics. Central European Journal of Biology 2:1-33 DOI:10.2478/s11535-007-0010-5.

Golkar Z, Bagasra O, Pace DG. 2014. Bacteriophage therapy: a potential solution for the antibiotic resistance crisis. Journal of Infection in Developing Countries 8:129-136 DOI: $10.3855 /$ jidc. 3573 .

Gottler LM, Ramamoorthy A. 2009. Structure, membrane orientation, mechanism, and function of pexiganan - a highly potent antimicrobial peptide designed from magainin. Biochimica et Biophysica Acta - Biomembranes 1788: 1680-86 DOI: 10.1016/j.bbamem.2008.10.009.

Gould IM, Bal AM. 2013. New antibiotic agents in the pipeline and how they can help overcome microbial resistance. Virulence 4: 185-191 DOI: 10.4161/viru.22507.

Grapsas I, Cho YJ, Mobashery S. 1994. N-(tert-butoxycarbonyloxy)-5-norbornene-endo-2, 3dicarboximide, a reagent for the regioselective introduction of the tert-butoxycarbonyl (boc) protective group at unhindered amines: Application to amino glycoside chemistry. The Journal of Organic Chemistry 59: 1918-1922 DOI: 10.1021/JO00086A055.

Greco I, Molchanova N, Holmedal E, Jenssen H, Hummel BD, Watts JL, Håkansson J, Hansen PR, Svenson J. 2020. Correlation between hemolytic activity, cytotoxicity and systemic in vivo toxicity of synthetic antimicrobial peptides. Scientific Reports 10: 13206 DOI: 10.1038/s41598-020-69995-9.

Groves ML. 1960. The isolation of a red protein from milk. Journal of the American Chemical 
626

627

628

629

630

631

632

633

634

635

636

637

638

639

640

641

642

643

644

645

646

647

648

649

650

651

652

653

654

655

656

657

658

659

660
Heng NCK, Tagg JR. 2006. What's in a name? Class distinction for bacteriocins. Nature Reviews Microbiology 4:160 DOI: 10.1038/nrmicro1273-c

Hirsch JG. 1956. Phagocytin: a bactericidal substance from polymorphonuclear leucocytes. Journal of Experimental Medicine 103:589-611 DOI: 10.1084/jem.103.5.589.

Hodges RS, Jiang Z, Whitehurst J, Mant CT. 2011. Development of antimicrobial peptides as therapeutic agents. Pharmaceutical Sciences Encyclopedia: Drug Discovery, Development, and Manufacturing DOI: 10.1002/9780470571224.pse430.

Hollmann A, Martinez M, Maturana P, Semorile LC, Maaffia PC. 2018. Antimicrobial peptides: interaction with model and biological membranes and synergism with chemical antibiotics. Frontiers in Chemistry 6:204 DOI: 10.3389/fchem.2018.00204.

Hultmark D, Steiner H, Rasmuson T, Boman HG. 1980. Insect immunity. Purification and properties of three inducible bactericidal proteins from hemolymph of immunized pupae of Hyalophora Cecropia. European journal of biochemistry / FEBS 16: 7-16 DOI: 10.1111/j.1432-1033.1980.tb05991.x.

Hunter H, Demcoe A, Jenssen H, Gutteberg T, Vogel H. 2005. Human lactoferricin is partially folded in aqueous solution and is better stabilized in a membrane mimetic solvent. Antimicrobial Agents and Chemotherapy 49: 3387-3395 DOI: 10.1128/AAC.49.8.3387-3395.2005

Jäkel CE, Meschenmoser K, Kim Y, Weiher H, Schmidt-Wolf IGH. 2012. Efficacy of a proapoptotic peptide towards cancer cells. In Vivo 26: 419-426.

Jenssen H, Hamili P, Hancock RE. 2006. Peptide antimicrobial agents. Clinical Microbiology Reviews 19: 491-511 DOI: 10.1128/CMR.00056-05.

Jiang Y, Chen Y, Song Z, Tan Z, Cheng J. 2021. Recent advances in design of antimicrobial peptides and polypeptides toward clinical translation. Advanced Drug Delivery Reviews 170: 261-280 DOI: 10.1016/j.addr.2020.12.016.

Jindal HM, Le CF, Yusof MYM, Velayuthan RD, Lee VS, Zain SM, Isa DM, Sekaran SD. 2015. Antimicrobial activity of novel synthetic peptides derived from indolicidin and ranalexin against Streptococcus pneumoniae. PLoS ONE 10: e0128532 DOI: 10.1371/journal.pone.0128532.

Kemp DS, Kerkman DJ. 1981. Models that demonstrate peptide-bond formation by prior thiol capture 2. Capture by organomercury derivatives. Tetrahedron Letters 22, 185-186 DOI: 10.1016/0040-4039(81)80050-0

Kemp DS, Leung SL, Kerkman DJ. 1981. Models that demonstrate peptide-bond formation by prior thiol capture 1. Capture by disulfide formation. Tetrahedron Letters 22, 181-184 DOI: $10.1016 / 0040-4039(81) 80049-4$ 
661

662

663

664

665

666

667

668

669

670

671

672

673

674

675

676

677

678

679

680

681

682

683

684

685

686

687

688

689

690

691

692

693

694

695

696

Kliger Y. 2010. Computational approaches to therapeutic peptide discovery. Peptide Scince 94, 701-710 DOI: 10.1002/bip.21458

King DS, Fields CG, Fields GB. 2009. A cleavage method which minimizes side reactions following fmoc solid phase peptide synthesis. International Journal of Peptide and Protein Research, 6(3):255-66 DOI: 10.1111/j.1399-3011.1990.tb00976.x

Kishi RNI, Stach-Machado D, de Lacorte Singulani J, Dos Santos CT, Fusco-Almeida AM, Cilli EM, Freitas-Astua J, Picchi SC, Machado MA. 2018. Evaluation of cytotoxicity features of antimicrobial peptides with potential to control bacterial diseases of citrus. PLoS ONE 13: e0203451 DOI: 10.1371/journal.pone.0203451.

Kiss G, Michl H. 1962. On the venomous skin secretion of the orange-speckled frog bombina variegate. Toxicon 1: 33-39

Koehbach J, Craik DJ. 2019. The vast structural diversity of antimicrobial peptides. Trends in Pharmacological Sciences 40: 517-528 DOI: 10.1016/j.tips.2019.04.012.

Kovaleva V, Bukhteeva I, Kit OY, Nesmelova IV. 2020. Plant defensins from a structural perspective. International Journal of Molecular Sciences 21: 5307 DOI: 10.3390/ijms21155307

Kumar P, Kizhakkedathu JN, Straus SK. 2018. Antimicrobial peptides: diversity, mechanism of action and strategies to improve the activity and biocompatibility in vivo. Biomolecules 8: 4 DOI: 10.3390/biom8010004.

Laws M, Shaaban A, Rahman KM. 2019. Antibiotic resistance breakers : current approaches and future directions. FEMS Microbiology Reviews 43: 490-516 DOI: 10.1093/femsre/fuz014.

Le CF, Fang CM, Sekaran SD. 2017. Intracellular targeting mechanisms by antimicrobial peptides. Antimicrobial Agents and Chemotherapy 61: e02340-16 DOI: 10.1128/AAC.02340-16.

Lee D, Hodges R. 2003. Structure-activity relationships of de novo designed cyclic antimicrobial peptides based on gramicidin S. Biopolymers 71: 28-48 DOI: 10.1002/bip.10374.

Legrand D, Elass E, Carpentier M, Mazurier J. 2005. Lactoferrin: a modulator of immune and inflammatory responses. Cellular and Molecular Life Sciences 62: 2549-2559 DOI: $10.1007 / \mathrm{s} 00018-005-5370-2$.

Lei J, Sun L, Huang S, Zhu C, Li P, He J, Mackey V, Coy DH, He Q. 2019. The antimicrobial peptides and their potential clinical applications. American Journal Translational Research 11: 3919-3931.

Lemaitre B, Nicolas E, Michaut L, Reichhart JM, Hoffmann JA. 1996. The dorsoventral regulatory gene cassette spätzle/toll/cactus controls the potent antifungal response in

Peer] reviewing PDF | (2021:03:58838:2:0:NEW 27 Aug 2021) 
698

699

700

701

702

703

704

705

706

707

708

709

710

711

712

713

714

715

716

717

718

719

720

721

722

723

724

725

726

727

728

729

730

731

732
Lichtenthaler FW. 2002. Emil fischer, his personality, his achievements, and his scientific progeny. Europian Journal of Organic Chemistry 24: 4095-4122 DOI: 10.1002/10990690(200212)2002:24>4095.

Li Y, Liu T, Liu Y, Tan Z, Ju Y, Yang Y, Dong W. 2019. Antimicrobial activity, membrane interaction and stability of the D-Amino acid substituted analogs of antimicrobial peptide W3R6. Journal of Photochemistry and Photobiology B: Biology 200:111645 DOI: 10.1016/j.jphotobiol.2019.111645.

Lin TY, Weibel DB. 2016. Organization and function of anionic phospholipids in bacteria. Applied Microbiology and Biotechnology 100:4255-4267 DOI: 10.1007/s00253-0167468-x.

Lu J, Xu H, Xia J, Ma J, Xu J, Li Y, Feng J. 2020. D- and unnatural amino acid substituted antimicrobial peptides with improved proteolytic resistance and their proteolytic degradation characteristics. Frontiers in Microbiology 11: 563030. DOI: $10.3389 /$ fmicb. 2020.563030

Macraea MB, Shannon KP, Rayner DM, Kaiser AM, Hoffman PN, French GL. 2001. A simultaneous outbreak on a neonatal unit of two strains of multiply antibiotic resistant Klebsiella pneumoniae controllable only by ward closure. Journal of Hospital Infection 49: 183-92 DOI:10.1053/jhin.2001.1066.

Maher S, McClean S. 2006. Investigation of the cytotoxicity of eukaryotic and prokaryotic antimicrobial peptides in intestinal epithelial cells in vitro. Biochemical Pharmacology 71: 1289-1298 DOI: 10.1016/j.bcp.2006.01.012.

Mahlapuu M, Håkansson J, Ringstad L, Björn C. 2016. Antimicrobial peptides : an emerging category of therapeutic agents. Frontiers in Cellular and Infection Microbiology 6:194 DOI: $10.3389 /$ fcimb.2016.00194.

Malanovic N, Lohner K. 2016. Antimicrobial peptides targeting Gram-Positive bacteria. Pharmaceuticals 9:59 DOI: 10.3390/ph9030059.

Mattick ATR, Hirsch A. 1947. Further observations on an inhibitory substance (nisin) from lactic streptococci. Lancet 250: 5-8 DOI: 10.1016/s0140-6736(47)90004-4.

Merrifield RB. 1963. Solid phase peptide synthesis I: Synthesis of a tetrapeptide. Journal of the American Chemical Society 85: 2149-2154 DOI: 10.1021/ja00897a025

Mcinnes C, Kondejewski LH, Hodges RS, Sykes BD. 2000. Development of the structural basis for antimicrobial and hemolytic activities of peptides based on gramicidin $\mathrm{S}$ and design of novel analogs using NMR spectroscopy. Journal of Biological Chemistry 275: 14287-14294 DOI: 10.1074/jbc.275.19.14287

Mirski T, Niemcewicz M, Bartoszcze M, Gryko R, Michalski A. 2018. Utilisation of peptides 
against microbial infections - a review. Annals of Agricultural and Environmental Medicine 25: 205-210 DOI: 10.26444/aaem/74471.

Moravej H, Moravej Z, Yazdanparast M, Heiat M, Mirhosseini A, Moghaddam MM, Mirnejad R. 2018. Antimicrobial peptides : features, action, and their resistance mechanisms in bacteria. Microbial Drug Resistance 24:747-767 DOI: 10.1089/mdr.2017.0392.

Morehead MS, Scarbrough C. 2018. Emergence of global antibiotic resistance. Primary Care: Clinic in Office Practices 45: 467-484 DOI: 10.1016/j.pop.2018.05.006.

Nakatsuji T, Gallo RL. 2012. Antimicrobial peptides: old molecules with new ideas. Journal of Investigative Dermatology 132: 887-895 DOI: 10.1038/jid.2011.387.

Natalia GB, Brendan WW, Sam JW. 2017. The importance of glycosylation of antimicrobial peptides: natural and synthetics approaches. Drug Discovery Today 22: 919-926 DOI: 10.1016/j.drudis.2017.02.001.

Ohtani K, Okada T, Yoshizumi H, Kagamiyama H. 1977. Complete primary structures of two subunits of purothionin A, a lethal protein for brewer's yeast from wheat flour. Journal of Biochemistry 82: 753-767 DOI: 10/1093/oxfordjournals.jbchem.a131752.

Oliveira JTA, Souza PFN, Vasconcelos IM, Dias LP, Martins TF, Van Tilburg MF, Guedes MIF, Sousa DOB. 2019. Mo-CBP - -PepI, Mo-CBP 3 -PepII, and Mo-CBP 3 -PepIII are synthetic antimicrobial peptides active against human pathogens by stimulating ROS generation and increasing plasma membrane permeability. Biochimie.157:10-21. DOI: 10.1016/j.biochi.2018.10.016.

Ong ZY, Cheng J, Huang Y, Xu K, Ji Z, Fan W, Yang YY. 2014. Effect of stereochemistry, chain length and sequence pattern on antimicrobial properties of short synthetic $\beta$-Sheet forming peptide amphiphiles. Biomaterials 35: 1315-1325 DOI: 10.1016/j.biomaterials.2013.10.053.

Ong ZY, Gao JS, Yang YY. 2013. Short synthetic $\beta$-sheet forming peptide amphiphiles as broad spectrum antimicrobials with antibiofilm and endotoxin neutralizing capabilities. Advanced Functional Materials 23: 3682-92 DOI: 10.1002/ adfm.201202850.

Pasupuleti M, Schmidtchen A, Malmsten M. 2011. Antimicrobial peptides: key components of the innate immune system. Critical Reviews in Biotechnology 32: 143-171 DOI: 10.3109/07388551.2011.594423.

Patch JA, Barron AE. 2003. Helical peptoid mimics of magainin-2 amide. Journal of the American Chemical Society 125: 12092-12093 DOI: 10.1021/ja037320d

Patrulea V, Borchard G, Jordan O. 2020. An update on antimicrobial peptides (AMPs) and their delivery strategies for wound infections. Pharmaceutics 12: 840 DOI: 10.3390/pharmaceutics 12090840

Pedersen SL, Tofteng AP, Malik L, Jensen KJ. 2012. Microwave heating in solid-phase peptide 
770

771

772

773

774

775

776

777

778

779

780

781

782

783

784

785

786

787

788

789

790

791

792

793

794

795

796

797

798

799

800

801

802

803 804

Peterson E, Kaur P. 2018. Antibiotic resistance mechanisms in bacteria: relationships between resistance determinants of antibiotic producers, environmental bacteria, and clinical pathogens.Frontiers in Microbiology 9: 2928 DOI: 10.3389/fmicb.2018.02928.

Pfalzgraff A, Brandenburg K, Weindl G. 2018. Antimicrobial peptides and their therapeutic potential for bacterial skin infections and wounds. Frontiers in Pharmacology 9: 281 DOI: $10.3389 /$ fphar.2018.00281.

Porto WF, Silva ON, Franco OL. 2012. "Prediction and rational design of antimicrobial peptides,” in Protein Structure, ed. E. Faraggi (London: InTech), 377-396.

Ramos-Martín F, D’Amelio N. 2021. Molecular basis of the anticancer and antibacterial properties of cecropinxj peptide: an in silico study. International Journal of Molecular Sciences 22: 691 DOI: 10.3390/ijms22020691.

Rathinakumar R, Walkenhorst WF, Wimley WC. 2009. Broad-spectrum antimicrobial peptides by rational combinatorial design and high-throughput ccreening: the importance of interfacial activity. Journal of American Chemical Society 131: 7609-7617 DOI: $10.1021 / \mathrm{ja} 8093247$.

Read AF, Woods RJ. 2014. Antibiotic resistance management. Evolution, Medicine and Public Health 2014:147 DOI: 10.1093/emph/eou024.

Rosengren KJ, Clark RJ, Daly NL, Göransson U, Jones A, Craik DJ. 2003. Microcin J25 has a threaded sidechain-to-backbone ring structure and not a head-to-tail cyclized backbone. Journal of the American Chemical Society 125: 12464-12474 DOI: 10.1021/ja0367703

Solá RJ, Griebenow K. 2009. Effects of glycosylation on the stability of protein pharmaceuticals. Journal of Pharmaceutical Scince 98: 1223-1245 DOI: 10.1002/jps.21504.

Sader HS, Fedler KA, Rennie RP, Stevens S, Jones RN. 2004. Omiganan pentahydrochloride (MBI 226), a topical 12-amino-acid cationic peptide: spectrum of antimicrobial activity and measurements of bactericidal activity. Antimicrobial Agents and Chemotherapy 48: 3112-3118 DOI: 10.1128/AAC.48.8.3112-3118.2004

Schnölzer M, Alewood P, Jones A, Alewood D, Kent SBH. 2009. In situ neutralization in bocchemistry solid phase peptide synthesis. International Journal of Peptide and Protein Research 40:180-93 DOI: 10.1111/j.1399-3011.1992.tb00291.x.

Selsted ME, Szklarek D, Lehrer RI. 1984. Purification and antibacterial activity of antimicrobial peptides of rabbit granulocytes. Infection and Immunity 45:150-154 DOI: 10.1128/iai.45.1.150-154.1984.

Selsted ME, Tang YQ, Morris WL, McGuire PA, Novotny MJ, Smith W, Henschen AH, Cullor JS. 1993. Purification, primary structures and antibacterial activities of beta-defensins,

Peer] reviewing PDF | (2021:03:58838:2:0:NEW 27 Aug 2021) 
805

806

807

808

809

810

811

812

813

814

815

816

817

818

819

820

821

822

823

824

825

826

827

828

829

830

831

832

833

834

835

836

837

838

839

840

841

a new family of antimicrobial peptides from bovine neutrophils. Journal of Biological Chemistry 268: 6641-6648 DOI: 10.1016/S0021-9258(18)53298-1

Sengupta S, Chattopadhyay MK, Grossart H. 2013. The multifaceted roles of antibiotics and antibiotic resistance in nature.Frontiers in Microbiology 4:47 DOI: 10.3389/fmicb.2013.00047.

Spellberg B, Gilbert DN. 2014. The future of antibiotics and resistance : a tribute to a career of leadership by John Bartlett. Clinical Infectious Diseases 59: 71-75 DOI: 10.1093/cid/ciu392.

Subczynski WK, Pasenkiewicz-Gierula M, Widomska J, Mainali L, Raguz M. 2018. High cholesterol/low cholesterol: effects in biological membranes review. Cell Biochemistry Biophysics 75: 369-385. DOI: 10.1007/s12013-017-0792-7.

Tran D, Tran PA, Tang YQ, Yuan J, Cole T, Selsted ME. 2002. Homodimeric $\theta$-defensins from Rhesus macaqueLeukocytes. Isolation, synthesis, antimicrobial activities, and bacterial binding properties of the cyclic peptides. Journal of Biological Chemistry 277: 30793084 DOI: 10.1074/jbc.M109117200.

Trotti A, Garden A, Wardey P, Symonds P, Langer C, Redman R, Pajak TF, Fleming TR, Henke M, Bourhis J, Rosenthal DI, Junor E, Cmelak A, Sheehan F, Pulliam J, Devitt-Risse P, Fuchs H Chambers M, O'Sullivan, Ang KK. 2004. A multinational, randomized phase iii trial of iseganan hcl oral solution for reducing the severity of oral mucositis in patients receiving radiotherapy for head-and-neck malignancy. International Journal of Radiation Oncology Biology Physics 58: 674-681 DOI: 10.1016/S03603016(03)01627-4.

Tymoszewska A, Diep DB, Wirtek P, Aleksandrzak-Piekarczyk T. 2017. The non-lantibiotic bacteriocin garvicin q targets man-pts in a broad spectrum of sensitive bacterial genera. Scientific Reports 7: 8359 DOI: 10.1038/s41598-017-09102-7.

Van Epps HL. 2006. René Dubos: unearthing antibiotics. Journal of Experimental Medicine 203: 259 DOI:10.1084/jem.2032fta.

Ventola CL. 2015. The antibiotic resistance crisis: part 1 : causes and threats. Pharmacology \& Therapeutics 40: 277-283

Wang KR, Zhang BZ, Zhang W, Yan JX, Li J, Wang R, . 2008. Antitumor effects, cell selectivity and structure-activity relationship of a novel antimicrobial peptide polybiaMPI. Peptides 29: 963-968 DOI: 10.1016/j.peptides.2008.01.015.

Wimley WC. 2019. Application of synthetic molecular evolution to the discovery of antimicrobial peptides. Advance in Experimental Medicine and Biology. 1117: 241-255 DOI: 10.1007/978-981-13-3588-4_13.

World Health Organization (WHO). 2020. Antibiotic resistance. Availabe at https://www.who.int/news-room/fact-sheets/detail/antibiotic-resistance 
842 Wright GD. 2014. Something old, something new : revisiting natural products in antibiotic

843

844

845

846

847

848

849

850

851

852

853

854

855

856

857

858

859

860 drug discovery 1. Canadian Journal of Microbiology 60: 147-154 DOI: 10.1139/cjm2014-0063.

Yeaman MR, Yount NY. 2003. Mechanisms of antimicrobial peptide action and resistance. Pharmacological Reviews 55: 27-55 DOI: 10.1124/pr.55.1.2

Zhao Y, Zhang M, Qiu S, Wang J, Peng J, Zhao P, Zhu R, Wang H, Li Y, Wang K, Yan W, Wang R. 2016. Antimicrobial activity and stability of the D-amino acid substituted derivatives of antimicrobial peptide polybia-MPI. AMB Express. 6: 122 DOI: 10.1186/s13568-016-0295-8.

Zharkova MS, Orlov DS, Golubeva OY, Chakchir OB, Eliseev IE, Grinchuk TM, Shamova OV. 2019. Application of antimicrobial peptides of the innate immune system in combination with conventional antibiotics - a novel way to combat antibiotic resistance? Frontiers in Cellular Infection Microbiology 9: 128 DOI: 10.3389/fcimb.2019.00128.

Zasloff M. 1987. Magainins, a class of antimicrobial peptides from Xenopus skin : isolation ,characterization of two active forms, and partial cDNA sequence of a precursor. Proceeding National Academy Sciences of the United States of America 84: 5449-5453 DOI: $10.1073 /$ pnas.84.15.5449.

Zasloff M. 2002. Antimicrobial peptides of multicellular organisms. Nature 415: 389-395 DOI:10.1038/415389a. 


\section{Table legends}

862 Table 1: The analogies between Naturally Occurring AMPs and Synthetic AMPs 
863 Figure's legends

864 Figure 1: Numbers of diversity of AMPs from the data repository of antimicrobial peptides 865 (DRAMP). Data obtained from http://dramp.cpu-bioinfor.org/browse/

866 Figure 2: Structure of AMPs. The PBD IDs for these structures are: (a) 2 K6O for LL-37

867 (10.2210/pdb2K6O/pdb) (b) 6MY3 for Gromesin (10.2210/pdb6MY3/pdb) (c) 1FD4 for

868 Human $\beta$ defensin 2 (10.2210/pdb1fd4/pdb) (d) 1 G89 for Indolicin (10.2210/pdb1G89/pdb)

869 and (e) 5T56 for Microcin J25 (10.2210/pdb5t56/pdb). Structural coordinates were obtained

870 from the RCSB Protein Data Bank (PDB) (https://www.rcsb.org/)

871 Figure 3: Bacterial resistance mechanisms to antibiotics and the mechanisms of AMPs in

872 bacteria. 


\section{Table $\mathbf{1}$ (on next page)}

Table 1 : The analogy between Naturally Occurring AMPs and Synthetic AMPs 
Table 1: The analogies between Naturally Occurring AMPs and Synthetic AMPs

\begin{tabular}{|c|c|c|c|}
\hline & $\begin{array}{c}\text { Naturally Occurring } \\
\text { AMPs }\end{array}$ & Synthetic AMPs & References \\
\hline Sources/Origin & $\begin{array}{l}\text {-Found in many tissues of } \\
\text { many different species } \\
\text {-Found in nearly all forms of } \\
\text { life, and mostly reported to be } \\
\text { isolated from eukaryotes, such } \\
\text { as animals, plants and fungi } \\
\text {-Found in prokaryotic cells }\end{array}$ & $\begin{array}{l}\text {-Non-natural sources } \\
\text {-Often created by mimicking } \\
\text { natural sequences }\end{array}$ & $\begin{array}{l}\text { (Jiang et al., 2021; } \\
\text { Kumar, } \\
\text { Kizhakkedathu, \& } \\
\text { Straus, 2018; } \\
\text { Nakatsuji \& Gallo } \\
\text { 2012) }\end{array}$ \\
\hline Content & $\begin{array}{l}\text {-Comprised of L-amino acids } \\
\text { recognizable by proteases }\end{array}$ & $\begin{array}{l}\text {-The rational design of } \\
\text { sequences comprising } \\
\text { analogous D-amino acids } \\
\text { substituted for L-amino acids }\end{array}$ & $\begin{array}{l}\text { (da Cunha et al., } \\
\text { 2017; Zhao et al., } \\
\text { 2016) }\end{array}$ \\
\hline $\begin{array}{l}\text { Discovery } \\
\text { methods }\end{array}$ & $\begin{array}{ll}\text {-Using classic } & \text { purification } \\
\text { and in } & \text { vitro and in } \\
\text { vivo techniques } & \end{array}$ & $\begin{array}{l}\text {-Combination of trial-and- } \\
\text { error experimentation, } \\
\text { screening, or computer aided } \\
\text { design (increasing the peptide } \\
\text { post-translational stability } \\
\text { without altering biological } \\
\text { function). }\end{array}$ & $\begin{array}{l}\text { (da Cunha et al., } \\
\text { 2017; Jiang et al., } \\
\text { 2021) }\end{array}$ \\
\hline Characteristics & $\begin{array}{l}\text {-Frequently susceptible to } \\
\text { protease degradation } \\
\text {-Low bioavailability (i.e. } \\
\text { presence of bioactive } \\
\text { molecules at usually low } \\
\text { levels). } \\
\text {-Low resistance to proteolytic } \\
\text { degradation resulting in shorter } \\
\text { half-lives }\end{array}$ & $\begin{array}{l}\text {-High bioavailability } \\
\text {-Longer half-lives in vivo, } \\
\text { while maintaining a similar } \\
\text { activity and selectivity. } \\
\text {-Designed to improve their } \\
\text { potential without side effects } \\
\text {-Incorporation of multiple } \\
\text { functions in the same peptide } \\
\text { sequence }\end{array}$ & $\begin{array}{l}\text { (Azmi, } \\
\text { Skwarczynski \& } \\
\text { Toth, 2016; da } \\
\text { Cunha et al., 2017; } \\
\text { Jiang et al., 2021; } \\
\text { Lei et al., 2019; Lu } \\
\text { et al., 2020; } \\
\text { Mahlapuu et al., } \\
\text { 2016; Wimley, } \\
\text { 2019) }\end{array}$ \\
\hline Examples & $\begin{array}{l}\text {-Protegerin } \\
\text {-Indolicin } \\
\text {-Magainin } 2 \\
\text {-Moringa oleifera chitin- } \\
\text { binding protein (Mo-CBP) }\end{array}$ & $\begin{array}{l}\text {-Iseganan (protegerin as } \\
\text { template) } \\
\text {-Omiganan (developed from } \\
\text { indolicin) } \\
\text {-Pexiganan (developed from } \\
\text { magainin 2) } \\
\text {-Mo-CBP }{ }_{3} \text {-PepIII (developed } \\
\text { from Mo-CBP) }\end{array}$ & $\begin{array}{l}\text { (Ge et al., 1999; } \\
\text { Gottler } \\
\text { Ramamoorthy, } \\
\text { 2009; Oliveira et } \\
\text { al., 2019; Sader et } \\
\text { al., 2004; Trotti et } \\
\text { al., 2004) }\end{array}$ \\
\hline
\end{tabular}


Figure 1

Numbers of diversity of AMPs from the data repository of antimicrobial peptides (DRAMP).

Data obtained from http://dramp.cpu-bioinfor.org/ browse/

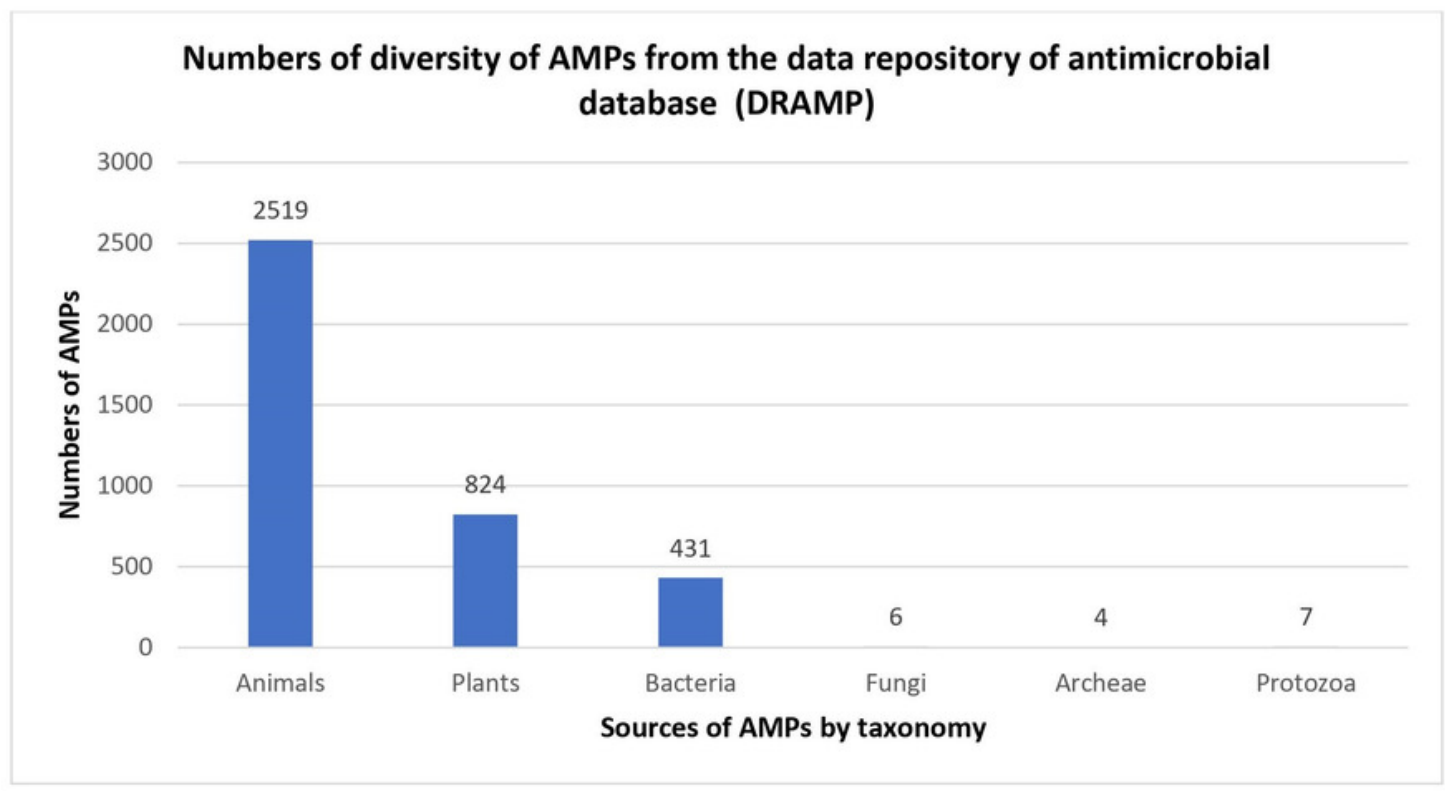


Figure 2

\section{Structure of AMPs.}

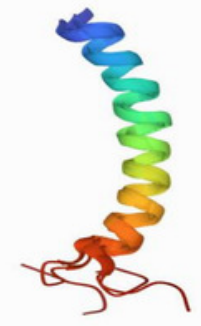

(a) LL-37 with $\alpha$-helices structure

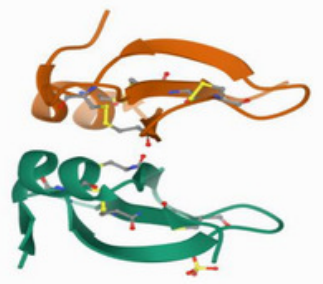

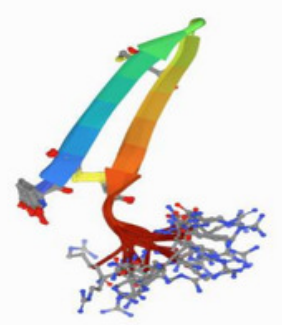

(b) Gomesin with $\boldsymbol{\beta}$-sheets structure

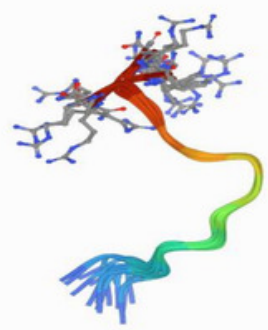

(c) Human $\beta$-defensin 2 with mixed structure

$(\alpha \beta)$ (d) Indolicin with extended structure

(non- $\boldsymbol{\alpha} \beta$ )

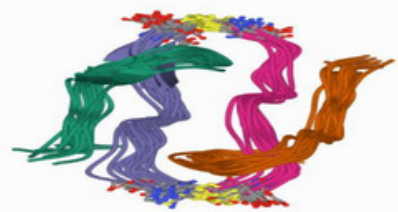

(e) Microcin $\mathbf{2} 25$ with cyclic peptide structure

Figure 2: Structure of AMPs. The PBD IDs for these structures are: (a) $2 \mathrm{~K} 6 \mathrm{O}$ for LL-37 (b) 6MY3 for Gromesin (c) 1 FD4 for Human $\beta$-defensin 2 (d) 1 G89 for Indolicin and (e) 5 T56 for Microcin J25. Structural coordinates were obtained from the RCSB Protein Data Bank (PDB) (https://www.rcsb.org/). 
Figure 3

Bacterial resistance mechanisms to antibiotics and the mechanisms of AMPs in bacteria.



